PROCESY KSZTALTOWANIA SIE UKLADÓW REGIONALNYCH PRZEMYSŁU

\author{
ZBIGNIEW ZiOŁO
}

\title{
Procesy transformacji przemysłowych układów przestrzennych na tle zmieniającego się otoczenia
}

Nasilające się procesy rozwoju cywilizacyjnego, przejawiające się w przechodzeniu z industrialnej i postindustrialnej fazy rozwoju do fazy społeczeństwa informacyjnego, stwarzają nowe uwarunkowania dla funkcjonowania różnorodnych podmiotów gospodarczych i instytucji, a także wymagają kształtowania nowych postaw społecznych i kulturowych władz samorządowych, grup społecznych i poszczególnych osób.

W tym złożonym procesie zmieniają się bowiem uwarunkowania funkcjonowania przedsiębiorstw przemysłowych, zróżnicowanych pod względem potencjału produkcyjnego, funkcji gospodarczych i struktury branżowej. Podczas gdy w latach industrialnego rozwoju wiodące funkcje spełniały zakłady bazujące na zasobach surowcowych (węgiel, rudy żelaza), związane z przemysłem ciężkim, czy zakłady bazujące na zasobach pracy (przemysł włókienniczy), to w fazie społeczeństwa informacyjnego funkcje te przejmują przemysły bazujące na wiedzy, zwłaszcza reprezentujące sektory „wysokiej techniki” (m.in. informatyka, elektronika, biotechnologia).

W światowej przestrzeni przemysłowej występują jednak duże zróżnicowania, które są wyrazem pewnego dystansu rozwojowego poszczególnych obszarów. Wskazuje na to m.in. struktura wartości sprzedanej 150 wiodących korporacji światowych, Europy Zachodniej i Europy Środkowo-Wschodniej. Wśród największych światowych korporacji najpoważniejszą rolę odgrywają: produkcja i usługi dla konsumentów, które obejmują 23,2\% ogólnej sprzedaży, produkcja i dystrybucja żywności (17,5\%), produkcja energii $(16,6 \%)$, zakłady przemysłowe produkujące środki transportu i maszyny i urządzenia $(13,3 \%)$; ich łączny udział w ogólnej sprzedaży wynosi 70,6\% (tab. 1). Kolejne pozycje zajmują sektory związane z ,wysokimi technologiami”, reprezentowane przez: usługi telekomunikacyjne, IT, opiekę zdrowotną (firmy farmaceutyczne); obejmują one łącznie 19,7\% wartości sprzedaży.

Podobnie w krajach Europy Zachodniej podstawowe znaczenie w zakresie wartości sprzedaży mają sektory: artykułów luksusowych $(21,3 \%)$, energetyka $(15,3 \%)$ oraz artykuły konsumpcyjne i przemysłowe, które łącznie obejmują 65,1\% ogólnej wartości sprzedaży (tab. 2).

Natomiast wśród wiodących firm Europy Środkowej i Wschodniej podstawową rolę odgrywa sektor paliw, który obejmuje aż 45,3\% ogólnej wartości sprzedaży, a następnie sektory związane jeszcze z industrialną fazą rozwoju (metalowy i transportowy), które łącznie obejmują 64,0\% wartości sprzedaży (tab. 3). 
Tabela 1. Wartość sprzedaży wiodących korporacji światowych w 2003 r.

\begin{tabular}{|c|c|c|c|c|}
\hline \multirow{2}{*}{ Sektory } & \multirow{2}{*}{$\begin{array}{l}\text { Liczba } \\
\text { firm }\end{array}$} & \multirow{2}{*}{$\begin{array}{c}\text { Wartość } \\
\text { sprzedaży } \\
\text { w mld USD }\end{array}$} & \multicolumn{2}{|c|}{ Struktura } \\
\hline & & & Firm & Sprzedaży \\
\hline Produkcja i usługi dla konsumentów & 29 & 1760,1 & 19,3 & 23,2 \\
\hline $\begin{array}{l}\text { Produkcja i dystrybucja artykułów } \\
\text { żywnościowych }\end{array}$ & 27 & 1331,9 & 18,0 & 17,5 \\
\hline Energia & 14 & 1264,0 & 9,3 & 16,6 \\
\hline Zakłady przemysłowe & 21 & 1009,9 & 14,0 & 13,3 \\
\hline Usługi telekomunikacyjne & 15 & 647,2 & 10,0 & 8,5 \\
\hline IT & 13 & 530,0 & 8,7 & 7,0 \\
\hline Opieka zdrowotna & 12 & 427,3 & 8,0 & 5,6 \\
\hline Energetyka & 8 & 312,2 & 5,3 & 4,1 \\
\hline Materiały & 11 & 311,1 & 7,3 & 4,1 \\
\hline Ogółem & 150 & 7593,9 & 100,0 & 100,0 \\
\hline
\end{tabular}

Źródło: Global 2003

Tabela 2. Wartość sprzedaży wiodących firm zachodnioeuropejskich w 2003 r.

\begin{tabular}{|c|c|c|c|c|}
\hline \multirow{2}{*}{ Sektory } & \multirow{2}{*}{ Liczba firm } & \multirow{2}{*}{$\begin{array}{c}\text { Wartość } \\
\text { sprzedaży } \\
\text { w mld euro }\end{array}$} & \multicolumn{2}{|c|}{ Struktura } \\
\hline & & & Firm & Sprzedaży \\
\hline Art. luksusowe & 29 & 734,2 & 19,3 & 21,3 \\
\hline Energetyka & 7 & 527,5 & 4,7 & 15,3 \\
\hline Art. konsumpcyjne & 22 & 502,8 & 14,7 & 14,6 \\
\hline Przemysł & 28 & 477,4 & 18,7 & 13,9 \\
\hline Telekomunikacja & 13 & 310,6 & 8,7 & 9,0 \\
\hline Usługi komunalne & 13 & 281,0 & 8,7 & 8,2 \\
\hline Surowce & 18 & 254,0 & 12,0 & 7,4 \\
\hline Opieka zdrowotna & 7 & 134,0 & 4,7 & 3,9 \\
\hline Energia & 2 & 88,6 & 1,3 & 2,6 \\
\hline Informatyka & 6 & 74,1 & 4,0 & 2,2 \\
\hline Surowce i materiały & 4 & 47,4 & 2,7 & 1,4 \\
\hline Usługi telekomunikacyjne & 1 & 11,8 & 0,7 & 0,3 \\
\hline Ogółem & 150 & 3443,4 & 100,0 & 100,0 \\
\hline
\end{tabular}


Tabela 3. Wiodące firmy Europy Środkowo-Wschodniej w 2003 r.

\begin{tabular}{|c|c|c|c|c|}
\hline \multirow{2}{*}{ Branża } & \multirow{2}{*}{$\begin{array}{l}\text { Liczba } \\
\text { firm }\end{array}$} & \multirow{2}{*}{$\begin{array}{l}\text { Wartość sprzedaży } \\
\text { w mln USD }\end{array}$} & \multicolumn{2}{|c|}{ Struktura } \\
\hline & & & Firm & Sprzedaży \\
\hline paliwa & 28 & 161683,7 & 18,7 & 45,3 \\
\hline metalowa & 21 & 34039,6 & 14,0 & 9,5 \\
\hline transportowa & 15 & 32821,7 & 10,0 & 9,2 \\
\hline energetyczna & 15 & 23098,6 & 10,0 & 6,5 \\
\hline telekomunikacyjna & 14 & 22648,1 & 9,3 & 6,3 \\
\hline handel & 21 & 20565,8 & 14,0 & 5,8 \\
\hline motoryzacyjna & 8 & 17611,8 & 5,3 & 4,9 \\
\hline wydobywcza & 7 & 11704,7 & 4,7 & 3,3 \\
\hline holding & 3 & 11551,3 & 2,0 & 3,2 \\
\hline elektrotechniczna & 7 & 11220,9 & 4,7 & 3,1 \\
\hline spożywcza & 3 & 2403,5 & 2,0 & 0,7 \\
\hline drzewna & 2 & 1764,6 & 1,3 & 0,5 \\
\hline usługi & 1 & 1512,0 & 0,7 & 0,4 \\
\hline tytoniowa & 1 & 1123,9 & 0,7 & 0,3 \\
\hline lasy & 1 & 1072,9 & 0,7 & 0,3 \\
\hline farmaceutyczna & 1 & 727,3 & 0,7 & 0,2 \\
\hline chemia & 1 & 650,0 & 0,7 & 0,2 \\
\hline budownictwo & 1 & 551,9 & 0,7 & 0,2 \\
\hline Ogółem & 150 & 356752,3 & 100,0 & 100,0 \\
\hline
\end{tabular}

Źródło: „Rzeczpospolita” z dn. 9 września 2004

Podczas gdy wśród najważniejszych światowych firm krajów ekonomicznie rozwiniętych dominującą pozycję zajmują korporacje reprezentujące przemysł nowoczesnych sektorów i produkujący dla konsumentów, to w krajach Europy Środkowej i Wschodniej dominują firmy surowcowe oraz sektory związane z industrialną fazą rozwoju. Wskazuje to na pewien dystans rozwojowy, który w celowo kreowanych procesach transformacji i restrukturyzacji przestrzennych układów przemysłowych w następnych latach będzie się stopniowo zmniejszać.

W przechodzeniu $\mathrm{z}$ industrialnej fazy rozwoju do fazy informacyjnej zróżnicowana przestrzeń geograficzna stwarzała określone uwarunkowania dla rozwoju i lokalizacji coraz to nowej działalności produkcyjnej, reprezentowanej przez różnego rodzaju przedsiębiorstwa przemysłowe. Kształtująca się pod wpływem zmieniających się uwarunkowań regionalnych struktura przestrzenna przemysłu, charakteryzująca się punktowym występowaniem zakładów wykazuje tendencje bądź do postępującej koncentracji przestrzennej zakładów przemysłowych, bądź do ich rozpraszania.

Postawą przestrzennej koncentracji zakładów przemysłowych w industrialnej fazie rozwoju były korzyści wspólnej lokalizacji, przejawiające się także w różnorodnych powiązaniach przestrzenno-produkcyjnych, dotyczących m.in. powiązań surowcowych, energetycznych, zagospodarowania w zakresie elementów sieciowej infrastruktury techniczno-ekonomicznej, powiązań stosunkami pracy czy rynków zbytu. Zróżnicowane natę- 
żenie przestrzennych sił skupiania zakładów przemysłowych, jak wskazuje bogata literatura przedmiotu, doprowadziło do wykształcania się zróżnicowanych pod względem potencjału produkcyjnego i struktury gałęziowej przestrzennych form koncentracji przemysłu, a to: skupień przemysłowych, zespołów przemysłowych, ośrodków przemysłowych, okręgów przemysłowych i kompleksów przemysłowych. Analizując formy koncentracji przemysłu w latach gospodarki centralnie sterowanej zwracano pewną uwagę na możliwości koordynacji funkcjonowania przedsiębiorstw przemysłowych w układach przestrzennych, celem podniesienia ich efektywności (m.in.: Kołosowski 1955, Secomski 1956, Bandman 1976, Misztal 1962, 1970, Pakuła 1962, Fajferek 1966, Fierla 1967, Kortus 1968, Byrski 1970, Probst 1974, Zioło 1970, 1971), podobnie przestrzenne skupianie zakładów i związane z nimi korzyści aglomeracji podkreślane były w literaturze zachodniej (Chardonnet 1955, Isard 1965, Boudeville 1966, Hamilton 1977). Idea przestrzennej współpracy między firmami wraca także obecnie; przedstawia się ją w formie klastrów. Wydaje się, że wykorzystanie dorobku teoretycznego i empirycznego dotyczącego zwłaszcza ośrodków i okręgów przemysłowych znacznie przyśpieszyłoby rozwijanie koncepcji klastrów, których obecne podstawy teoretyczne i prace empiryczne znacznie odbiegają warsztatowo od analiz wspomnianych form koncentracji przemysłu ${ }^{1}$.

Z punktu widzenia analizy procesów transformacji główną uwagę zwrócimy na przestrzenne układy przemysłowe reprezentowane przez wymienione formy koncentracji przemysłu. Analizując te formy wspomniani Autorzy przyjmowali, iż ich podstawowymi elementami są zakłady przemysłowe. Przestrzenne formy koncentracji przemysłu (zespoły, ośrodki, okręgi) nie stanowią zbioru jednorodnych zakładów przemysłowych, ale obejmują firmy o różnym potencjale produkcyjnym, spełniające różne funkcje w gospodarce oraz reprezentujące różnorodne gałęzie. Zakłady te zlokalizowane są na terenie jednej lub kilku sąsiadujących ze sobą lub położonych w niewielkiej odległości od siebie jednostek osadniczych.

W literaturze przedmiotu przestrzenne układy przemysłowe wyróżniano także biorąc pod uwagę potencjał przemysłowy występujący na terenie określonych jednostek przestrzennych, za które przyjmowano powiaty lub gminy. Na podstawie przyjętych mierników potencjału oraz wskaźników uprzemysłowienia wyróżniano obszary o różnym stopniu uprzemysłowienia (Leszczycki, Grzeszczak, Kukliński, Najgrakowski 1961, Fierla 1967, Herman 1967, Gierańczyk, Stańczyk 2001).

Biorąc pod uwagę założenia teorii bazy ekonomicznej (Dziewoński 1967) oraz określoną na jej podstawie funkcję zakładów przemysłowych, w strukturze przestrzennych układów przemysłowych możemy wyróżnić zakłady o funkcjach egzogenicznych i endogenicznych. Funkcje egzogeniczne reprezentują zakłady: wiodące (charakteryzujące się dużym potencjałem produkcyjnym oraz pracujące na potrzeby otoczenia krajowego i międzynarodowego), komplementarne (pracujące głównie na potrzeby zakładów wiodących) i standardowe (pracujące na potrzeby regionalne). Zakłady o funkcjach endogenicznych pracują głównie na potrzeby gospodarki lokalnej i ponadlokalnej (Zioło 1976, 1980).

Poszczególne typy zakładów przemysłowych nie funkcjonują samodzielnie, ale odznaczają się różnorodnymi relacjami zachodzącymi między nimi oraz między różnymi kategoriami otoczenia (regionalne, krajowe, międzynarodowe). Zagadnienie to ilustruje tablica przedstawiająca uproszczony model funkcjonowania przestrzennego układu przemysłowego

${ }^{1}$ Problematyka badawcza tych form koncentracji została przedstawiona w pracach zbiorowych dotyczących przedsiębiorstwa przemysłowego (Zioło 1988), ośrodka przemysłowego (Zioło 1990) i okręgu przemysłowego (Zioło 1993). 
w jego otoczeniu. W modelu wyróżniono cztery bloki macierzy, które przedstawiają określone relacje występujące między wyróżnionymi typami przedsiębiorstw a kategoriami otoczenia (tab. 4).

Tabela 4. Model funkcjonowanie przestrzennego układu przemysłowego

\begin{tabular}{|c|c|c|c|c|c|c|c|}
\hline \multirow[b]{2}{*}{$\begin{array}{l}\text { Funkcje zakładów, } \\
\text { kategorie otoczenia }\end{array}$} & \multicolumn{3}{|c|}{ Egzogeniczne } & \multirow[b]{2}{*}{ Egzogeniczne } & \multicolumn{3}{|c|}{ Otoczenie } \\
\hline & 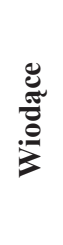 & 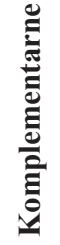 & & & 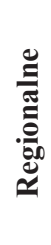 & 菊 & 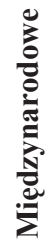 \\
\hline \multicolumn{8}{|l|}{ Egzogeniczne: } \\
\hline Wiodące - W & $\mathrm{W}^{\mathrm{w}}$ & $\mathrm{W}^{\mathrm{k}}$ & $\mathrm{W}^{\mathrm{s}}$ & $\mathrm{W}^{\mathrm{e}}$ & $\mathrm{W}^{\mathrm{p}}$ & $\mathrm{W}^{\mathrm{c}}$ & $\mathrm{W}^{\mathrm{g}}$ \\
\hline Komplementarne $-\mathrm{K}$ & $\mathrm{K}^{\mathrm{w}}$ & $\mathrm{K}^{\mathrm{k}}$ & $\mathrm{K}^{\mathrm{s}}$ & $\mathrm{K}^{\mathrm{e}}$ & $\mathrm{K}^{\mathrm{p}}$ & $\mathrm{K}^{\mathrm{c}}$ & $\mathrm{K}^{\mathrm{g}}$ \\
\hline Standardowe $-\mathrm{S}$ & $\mathrm{S}^{\mathrm{w}}$ & $\mathrm{S}^{\mathrm{k}}$ & $\mathrm{S}^{\mathrm{s}}$ & $\mathrm{S}^{\mathrm{e}}$ & $\mathrm{S}^{\mathrm{p}}$ & $\mathrm{S}^{\mathrm{c}}$ & S. ${ }^{c}$ \\
\hline Egzogeniczne-E & $\mathrm{E}^{\mathrm{w}}$ & $\mathrm{E}^{\mathrm{k}}$ & $E^{s}$ & $\mathrm{E}^{\mathrm{e}}$ & $E^{p}$ & $\mathrm{E}^{\mathrm{c}}$ & $\mathrm{E}^{\mathrm{c}}$ \\
\hline \multicolumn{8}{|l|}{ Otoczenie: } \\
\hline Regionalne $-\mathrm{P}$ & $\mathrm{P}^{\mathrm{w}}$ & $\mathrm{P}^{\mathrm{k}}$ & $\mathrm{P}^{\mathrm{s}}$ & $\mathrm{P}^{\mathrm{e}}$ & $\mathrm{P}^{\mathrm{p}}$ & $\mathrm{P}^{\mathrm{c}}$ & $\mathrm{P}^{\mathrm{g}}$ \\
\hline Krajowe $-\mathrm{C}$ & $\mathrm{C}^{\mathrm{w}}$ & $\mathrm{C}^{\mathrm{k}}$ & $\mathrm{C}^{\mathrm{s}}$ & $\mathrm{C}^{\mathrm{e}}$ & $\mathrm{C}^{\mathrm{p}}$ & $\mathrm{C}^{\mathrm{c}}$ & $\mathrm{C}^{\mathrm{g}}$ \\
\hline Międzynarodowe - G & $\mathrm{G}^{\mathrm{w}}$ & $\mathrm{G}^{\mathrm{k}}$ & $\mathrm{G}^{\mathrm{s}}$ & $\mathrm{G}^{\mathrm{e}}$ & $\mathrm{G}^{\mathrm{p}}$ & $\mathrm{G}^{\mathrm{c}}$ & $\mathrm{G}^{\mathrm{g}}$ \\
\hline
\end{tabular}

Źródło: Opracowanie własne

Pierwszy blok macierzy obejmuje powiązania wewnętrzne występujące w strukturze przestrzennego układu przemysłowego:

1) powiązania między tymi samymi kategoriami funkcjonalnymi zakładów:

- między zakładami wiodącymi - $\mathrm{W}^{\mathrm{w}}$,

- między zakładami komplementarnymi - $\mathrm{K}^{\mathrm{k}}$,

- między zakładami standardowymi - Ss,

- między zakładami o funkcjach endegemicznych - $\mathrm{E}^{\mathrm{e}}$;

2) powiązania pasywne (kolumny macierzy) i aktywne (wiersze macierzy) między poszczególnymi typami funkcjonalnymi, np.

- wpływ zakładów wiodących (W) na zakłady komplementarne (K) przedstawia macierz $\mathrm{W}^{\mathrm{k}}$,

- wpływ zakładów komplementarnych (K) na zakłady wiodące (W) przedstawia macierz $\mathrm{K}^{\mathrm{w}}$,

Oznacza to, iż macierze $\mathrm{W}^{\mathrm{k}}$ i $\mathrm{K}^{\mathrm{w}}$ nie są sobie równe i przedstawiają odmienne relacje. Pierwsza z nich określa powiązania aktywne elementów wiodących (W) w stosunku do elementów komplementarnych, druga powiązania pasywne elementów wiodących (W), czyli oddziaływanie na nie elementów komplementarnych (K). 
Drugi blok macierzy ilustruje powiązania aktywne wyróżnionych typów zakładów $\mathrm{z}$ różnymi kategoriami otoczenia: regionalnym, krajowym, międzynarodowym,

Przedstawiają one, np.:

- wpływ zakładów wiodących (W) na otoczenie międzynarodowe $(\mathrm{G})$, które określa macierz $\mathrm{W}^{\mathrm{g}}$,

- wpływ zakładów standardowych na otoczenie regionalne, które określa macierz Sp.

Trzeci blok macierzy przedstawia wpływ różnej kategorii otoczenia (powiązania pasywne) na wyróżnione typy funkcjonalne zakładów przemysłowych, np.:

- wpływ otoczenia międzynarodowego $(\mathrm{G})$ na zakłady wiodące $(\mathrm{W})-\mathrm{G}^{\mathrm{w}}$,

- wpływ otoczenia regionalnego (P) na zakłady standardowe $(\mathrm{S})-\mathrm{P}^{\mathrm{s}}$.

Dla podejmowania działań w zakresie sterowania procesami transformacji czy restrukturyzacji poszczególnych typów funkcjonalnych zakładów przemysłowych bardzo ważnych informacji dostarcza czwarty blok macierzy. Określa on relacje zachodzące w poszczególnych kategoriach otoczenia (regionalnym, krajowym czy międzynarodowym) oraz relacje między nimi. Występują w nim:

- macierze odnoszące się do powiązań występujących w poszczególnych kategoriach otoczenia: regionalnego $-\mathrm{P}^{\mathrm{p}}$, krajowego $-\mathrm{C}^{\mathrm{c}}$, międzynarodowego $-\mathrm{G}^{\mathrm{g}}$,

- macierze określające aktywne (wiersze macierzy) i pasywne (kolumny macierzy) relacje występujące między poszczególnymi kategoriami otoczenia, np. wpływ otoczenia międzynarodowego $(\mathrm{G})$ na otoczenie krajowe $(\mathrm{C})$ określa macierz $\mathrm{G}^{\mathrm{c}}$; a odwrotne relacje, czyli wpływ otoczenia krajowego $(\mathrm{C})$ na otoczenie międzynarodowe określa macierz $\mathrm{C}^{\mathrm{g}}$. Natomiast wpływ otoczenia międzynarodowego $(\mathrm{G})$ na otoczenie regionalne (P) określa macierz $\mathrm{G}^{\mathrm{p}}$.

Analiza tych relacji pozwala na śledzenie procesów transformacji (przemian) dokonujących się w wyróżnionych kategoriach otoczenia. Analiza ich stwarza pewne przesłanki do sterowania procesami przemian poszczególnych kategorii zakładów w zakresie zmian rynkowych wywołanych zmiennością warunków otoczenia.

$\mathrm{Z}$ punktu widzenia procesów transformacji przestrzennych układów przemysłowych szczególne znaczenie mają więc badania prawidłowości występujących między poszczególnymi kategoriami otoczenia oraz ich oddziaływania pasywnego i aktywnego na poszczególne kategorie funkcjonalne zakładów oraz relacje między nimi. Oddziaływania te mogą się przejawiać w formie różnorodnych impulsów, które mogą występować jako czynniki pobudzające wzrost danych typów czy określonego zakładu, ale także mogą być barierami ograniczającymi funkcjonowanie i rozwój zakładów. Ma to szczególne znaczenie dla zarządów poszczególnych firm, a także związanych z nimi samorządowych władz lokalnych i regionalnych. Opierając się na celowo wykonywanych studiach diagnostycznych powinny oni podejmować odpowiednie działania mające na celu przyciąganie czynników z otoczenia, które będą dynamizować rozwój firm, przy równoczesnym ograniczaniu potencjalnych czy istniejących barier ograniczających ich napływ, a także zmierzać do generowania wewnętrznych czynników rozwoju.

Przedstawione rozważania wskazują, iż przestrzenne układy przemysłowe nie są sumą zakładów, ale kształtują się jako określone systemy, powstałe na zasadzie powiązań funkcjonalnych między poszczególnymi przedsiębiorstwami oraz ich otoczeniem. Oznacza to, iż procesy przemian dokonujące się w jednym zakładzie przemysłowym lub w jego otoczeniu, wpływają na zmianę sytuacji w pozostałych kategoriach zakładów przemysłowych oraz w poszczególnych kategoriach otoczenia. 
Dla przestrzennych układów przemysłowych, a także struktur lokalnych czy regionalnych szczególne znaczenie mają zakłady wiodące o znacznym potencjale produkcyjnym. Mają one swój udział w krajowym i międzynarodowym podziale pracy, które poprzez sieci różnorodnych powiązań aktywnych i pasywnych, w układach regionalnych pełnią funkcję motorycznych elementów rozwojowych (Zioło 1976, 1980). Na ich tempo rozwoju w zasadniczym stopniu wpływa otoczenie międzynarodowe ${ }^{2}$. Z jednej strony może ono stwarzać zapotrzebowanie na określone produkty, a z drugiej - może przyczyniać się do ograniczania zapotrzebowania na oferowane wyroby. Osłabienie lub upadek danego typu zakładu na zasadzie złożonego systemu sprzężeń aktywnych i pasywnych wpływa na pozostałe kategorie zakładów oraz na sytuację społeczną i ekonomiczną lokalnego czy regionalnego układu samorządowego. Upadek przedsiębiorstwa wpływa na zwiększanie rozmiarów bezrobocia, ograniczanie źródeł zasilania finansowego gospodarstw domowych, co z kolei stwarza rosnącą barierę popytową, ograniczającą funkcjonowanie rynku, a w konsekwencji negatywnie oddziaływuje na rozmiary produkcji kierowanej na rynek.

W warunkach pewnego nasycenia rynku przedsiębiorstwo musi, w nawiązaniu do zmieniających się uwarunkowań, dostarczać produkt konkurencyjny, w przeciwnym wypadku jest ono skazane na recesję lub upadek. Pewnym przykładem tej sytuacji są obecnie zachowania na rynku samochodowym Stanów Zjednoczonych dwóch wiodących koncernów samochodowych: General Motors Corporation (GM) i Toyoty. W porównaniu z sierpniem 2005 r., we wrześniu sprzedaż Toyoty w USA zwiększyła się o 10\%, podczas gdy sprzedaż GM spadła o $24 \%$, a Forda o $20 \%{ }^{3}$. W konsekwencji japoński koncern nie ma trudności finansowych i nie ma na składzie nadmiernych zapasów, natomiast GM znalazł się w poważnym kryzysie, wynikającym z zakłóceń w zakresie płynności finansowej. Wobec rosnącej ceny paliwa, dochodzącej do 3 dol. za galon (3,8 litra), Amerykanie ,polubili” samochody japońskiego koncernu zużywające o prawie połowę mniej paliwa. Wpłynęło to również na znaczny wzrost rynkowej wartości koncernu Toyota (o 10 mld dol. USD), osiągając poziom $168 \mathrm{mld}$ dol. USD ${ }^{4}$. Osiągnięcie tego sukcesu przez japoński koncern wymagało przyjęcia długoletniej strategii rozwoju, kładącej nacisk na niezawodność pojazdu oraz spełnianie przez niego wymogów ekologicznych i ekonomicznych. Było to możliwe poprzez zaostrzenie systemu kontroli jakości oraz poniesienie znacznych wydatków na badania i rozwój, które wyniosły 5,7 mld dol. USD 5 . Umożliwiło to koncernowi Toyota opanowywanie nowych rynków, wyrazem czego jest przestrzenne rozmieszczenie jej fabryk. W 2005 r. 61 fabryk tego koncernu występowało na terenie 26 krajów, w tym w Japonii (15 fabryk), Chinach (13), po trzy fabryki w Malezji i Tajlandii oraz po dwie w USA, Kanadzie, Filipinach, Wielkiej Brytanii i Polsce. By utrzymać swoją pozycję na światowym rynku GM planuje zamknięcie kilku fabryk i zwolnienie ok. 30 tys. pracowników. W podobnej sytuacji znalazł się koncern Forda,

${ }^{2}$ Należy zaznaczyć, iż losy gospodarki amerykańskiej, japońskiej czy chińskiej mają ogromne znaczenie dla reszty świata. Słabość tej gospodarki oraz np. związane z tym ograniczenie przez nią importu znacznie by osłabiło gospodarki pozostałych krajów.

${ }^{3}$ D. Walewska, Amerykanie zostali za Toyota, ,Rzeczpospolita” z dnia 5 października 2005 r.

${ }^{4}$ Dla porównania, PKB Polski w 2003 r. wynosił 209,6 mld dol. USD.

${ }^{5}$ Dla porównania, w 2003 r. wydatki z budżetu państwa na naukę wynosiły $207 \mathrm{mln}$ zł, tj. 1,4\% ogólnych wydatków, czyli 0,3\% PKB, a na szkolnictwo wyższe $701 \mathrm{mln}$ zł, tj 3,7\% wydatków ogólnych, czyli 0,9\% PKB, (za: Rocznik Statystyczny GUS 2004, s. 622). W przeliczeniu, według kursu miesięcznego ogłoszonego w dniu 23 września 2005 r. (za: „Gazeta Wyborcza” z dnia 26 września 2005 r.) wynoszącego 3,2931 zł za 1 dolara, nakłady na naukę wynosiły 0,062 mld dol., a na szkolnictwo wyższe 0,213 mld dol. 
który do 2012 r. planuje zamknąć na terenie USA 14 fabryk, a ich moce produkcyjne zmniejszyć o $25 \%$.

W dotychczasowych pracach badawczych i praktyce gospodarczej restrukturyzacja przedsiębiorstw przemysłowych była rozpatrywana z pozycji mikroekonomicznej - zachowania przedsiębiorstwa przemysłowego - i odnosiła się do wybranych jego aspektów ${ }^{6}$. Najczęściej dotyczyły one zmian struktury własności, poszukiwania inwestora strategicznego, możliwości utrzymania lub nawiązania nowych powiązań kooperacyjnych, najczęściej z zagranicznymi korporacjami przemysłowymi. Natomiast w mniejszym stopniu uwzględniano dotychczasowe powiązania przestrzenno-produkcyjne danego zakładu, występujące w strukturze układu lokalnego, regionalnego, krajowego czy międzynarodowego. W wyniku przebudowy systemu gospodarczego następowało bowiem rozrywanie dotychczasowych więzi technologicznych wykształconych w poprzednim okresie czasu. W konsekwencji tworzone dla nich programy naprawcze z góry skazane były na niepowodzenie. Dobrym tego przykładem jest zachowanie się zakładów powstałych w ramach Centralnego Okręgu Przemysłowego i rozwijanych w latach gospodarki centralnie sterowanej. Powiązania technologiczne występujące między poszczególnymi zakładami oraz z własnym zapleczem naukowo-badawczym, a także z układami lokalnymi zostały porozrywane, co z góry skazało je na poważną recesję, a nawet upadek. Gdyby dokonana była wcześniej precyzyjna analiza wykształconych relacji, wskazałaby na wykształcony układ funkcjonalny zakładów. Do nich powinny nawiązać działania restrukturyzacyjne firm obszaru COP-u, by w ten sposób ograniczyć negatywne skutki tych działań. Natomiast porozrywanie wykształconych wcześniej powiązań technologicznych i rynkowych nie mogło dać zadowalających rezultatów.

W wyniku odmiennych mechanizmów zaznaczających się w otoczeniu światowym nastapił upadek przemysłu siarkowego. Znaczny postęp technologiczny i cywilizacyjny był główną przyczyną upadku krajowego przemysłu siarkowego, który w niedalekiej przeszłości odgrywał znaczącą rolę w skali światowej i był podstawowym czynnikiem motorycznym rozwoju regionalnego. Na upadek tego przemysłu w zasadniczym stopniu wpłynęły zmiany związane z postępem technicznym, które gwałtowanie zmieniły uwarunkowania na światowym rynku siarki. W latach intensywnego rozwoju przemysłu siarkowego ok. 80\% krajowej produkcji tego surowca kierowana była na rynki zagraniczne, głównie krajów zachodnich opierających swoją gospodarkę na regułach rynkowych. W ogólnym bilansie tego surowca ok. 75\% produkcji siarki kierowana była do produkcji kwasu siarkowego, a z kolei ok. 70\% kwasu siarkowego służyło do produkcji nawozów fosforowych. W wyniku postępu technologicznego oraz przesłanek ekologicznych udoskonalano produkcję nawozów, wytwarzając tzw. nawozy wieloskładnikowe, w wyniku czego zmniejszyło się zapotrzebowanie na produkowane wcześniej nawozy tradycyjne, a w konsekwencji ograniczało to produkcję kwasu siarkowego z siarki rodzimej. Równocześnie w latach zmian systemu gospodarowania i ograniczenia powiązań rynkowych z krajami Europy Środkowej i Wschodniej pojawiły się na krajowym rynku duże nadwyżki produkcji rolniczej, co wpłynęło także na zmniejszenie zapotrzebowania na nawozy.

Rozwijającej się gospodarce światowej towarzyszyło zwiększenie zapotrzebowania na produkty ropopochodne, co pociągnęło za sobą podejmowanie eksploatacji ropy naftowej i gazu w znacznym stopniu zasiarczonych. Wystapiła więc pilna potrzeba rozwijania metod odsiarczania ropy i gazu, w wyniku czego na składowiskach pojawiły się znaczne ilości

${ }^{6}$ Por. ostanie tomy Prac Komisji Geografii Przemysłu PTG. 
siarki pylastej, które traktowane były jako odpady produkcyjne i szkodliwe dla środowiska. Opanowanie metody przetwarzania siarki z postaci pylastej w postać siarki granulowanej umożliwiało jej transport oraz wykorzystanie jej do celów produkcyjnych. Dotowana utylizacja siarki odpadowej była więc znacznie tańsza od eksploatowanej w Polsce siarki rodzimej, co w zasadniczym stopniu przyczyniło się do obniżenia jej pozycji konkurencyjnej na rynku i upadku krajowego przemysłu siarkowego. W strukturze organizacyjnej przemysłu siarkowego funkcjonowały nowocześnie wyposażone Zakłady Mechaniczne, które wcześniej znane były w skali międzynarodowej m.in. z remontu największych obrabiarek i w latach transformacji gospodarczej, przy właściwym zarządzaniu majątkiem, zamiast upadać powinny przejąć nowe funkcje produkcyjno-usługowe.

W procesach transformacji przedsiębiorstw przemysłowych ważną kategorię otoczenia międzynarodowego stanowią ponadnarodowe koncerny. W drodze różnych form prywatyzacji oddziaływują one na określone przedsiębiorstwa, prowadząc do:

- upadku zakładu, pozbywając się najczęściej w ten sposób konkurenta dla swoich produktów, czemu towarzyszą często zjawiska patologiczne,

- włączania istniejących zakładów w swoje struktury organizacyjne, przekazując im produkcję określonych wyrobów lub podzespołów na zasadzie powiązań kooperacyjnych; tworzą równocześnie nowe powiązania logistyczne i przejmują istniejące wcześniej rynki dla swoich produktów; prowadzi to do zerwania istniejących wcześniej relacji produkcyjnych z innymi zakładami, co przyczynia się do ich recesji czy upadku.

- tworzenia nowych oddziałów produkcyjnych, usługowych, handlowych, usług finansowych i innych.

W wyniku procesów transformacji przestrzenne układy przemysłowe mogą odznaczać się wzrostem, stagnacją lub recesją. Na ich przemiany w głównym stopniu wpływa zachowanie się występujących $\mathrm{w}$ ich strukturze zróżnicowanych funkcjonalnie zakładów przemysłowych. W strukturze przestrzennego układu przemysłowego poszczególne zakłady mogą zachowywać się jako elementy: zanikłe, zanikające, stagnujące i nowo pojawiające się (Zioło 1986). W zależności od funkcji zakładu w strukturze danego układu przestrzennego zachowania te $\mathrm{w}$ głównym stopniu związane są ze zmieniającą się sytuacją w określonej kategorii otoczenia oraz z uwarunkowaniami wewnętrznymi, wynikającymi często z jakości zarządzania.

Interesująca próbę klasyfikacji zachowań przedsiębiorstw przemysłowych przedstawił T. Rachwał (2006), który w świetle badań empirycznych na terenie Polski PołudniowoWschodniej wyróżnił szereg typów zakładów, a to: zakłady rozwijające się, które przeszły pierwszy etap restrukturyzacji naprawczej, zakłady poszukujące nowych dróg rozwoju, które nie zakończyły jeszcze restrukturyzacji oraz zakłady zanikające, które nie znalazły swojego miejsca w nowych warunkach.

W nawiązaniu do nasilających się procesów integracji europejskiej ważną kategorią otoczenia transformacji przemysłu jest coraz silniej zaznaczająca się tendencja do zwiększania roli samorządowych struktur administracyjnych w zakresie zarządzania układami regionalnymi i lokalnymi, a więc i przestrzennymi układami przemysłowymi, przy stopniowym osłabianiu roli centralnej władzy państwa. Przejawem tego jest już obecnie duża samodzielność władz wojewódzkich w zakresie przygotowywania strategii rozwoju, a także możliwości nawiązywania współpracy międzynarodowej czy bezpośredniego starania się o fundusze w instytucjach Unii Europejskiej. 
Spośród regionalnych uwarunkowań na przyciaganie zewnętrznych impulsów rozwojowych oraz transformacje struktur przemysłowych w znacznym stopniu wpływają zróżnicowane w skali międzynarodowej koszty pracy oraz poziom wykształcenia społeczeństwa (tab. 5). W 2003 r. koszt jednej godziny pracy w wybranych krajach wahał się od 0,39 dol. w Indonezji, 0,80 dol. w Chinach, do 30,6 dol. w Niemczech i 21,9 dol. w USA, przy średnim koszcie w Polsce 2,7 dol. Stąd ważnym czynnikiem podnoszącym atrakcyjność krajowych układów regionalnych dla napływu zewnętrznych czynników rozwoju może być coraz lepiej wykształcone społeczeństwo, na co w poważnym stopniu mogą wpływać regionalne i lokalne władze samorządowe.

Tabela 5. Koszt godziny pracy w wybranych krajach w 2003 r. (w dol.)

\begin{tabular}{|l|c|c|c|c|}
\hline \multicolumn{1}{|c|}{ Kraje } & $\begin{array}{c}\text { Koszt godziny pracy } \\
\text { (w dolarach) }\end{array}$ & Indonezja = 100 & Niemcy = 100 & Polska = 100 \\
\hline Indonezja & 0,39 & 100,0 & 1,3 & 14,4 \\
\hline Chiny & 0,80 & 205,1 & 2,6 & 29,6 \\
\hline Indie & 1,12 & 287,2 & 3,7 & 41,5 \\
\hline Rosja & 1,50 & 384,6 & 4,9 & 55,6 \\
\hline Tajlandia & 1,96 & 502,6 & 6,4 & 72,6 \\
\hline Malezja & 2,09 & 535,9 & 6,8 & 77,4 \\
\hline Meksyk & 2,45 & 628,2 & 8,0 & 90,7 \\
\hline Polska & 2,70 & 692,3 & 8,8 & 100,0 \\
\hline Brazylia & 2,75 & 705,1 & 9,0 & 101,9 \\
\hline Węgry & 3,53 & 905,1 & 11,5 & 130,7 \\
\hline Czechy & 3,64 & 933,3 & 11,9 & 134,8 \\
\hline Tajwan & 5,67 & 1453,8 & 18,5 & 210,0 \\
\hline Korea & 9,99 & 2561,5 & 32,6 & 370,0 \\
\hline Hiszpania & 12,32 & 3159,0 & 40,3 & 456,3 \\
\hline Włochy & 16,56 & 4246,2 & 54,1 & 613,3 \\
\hline Francja & 17,77 & 4556,4 & 58,1 & 658,1 \\
\hline Wielka Brytania & 17,87 & 4582,1 & 58,4 & 661,9 \\
\hline Kanada & 18,44 & 4728,2 & 60,3 & 683,0 \\
\hline Japonia & 20,68 & 5302,6 & 67,6 & 765,9 \\
\hline USA & 21,86 & 5605,1 & 71,4 & 809,6 \\
\hline Niemcy & 30,60 & 7846,2 & 100,0 & 1133,3 \\
\hline
\end{tabular}

W koszt pracy wliczono wszystkie obciążenia jakie ponosi pracodawca

Źródło: BCG, za: „Gazeta Wyborcza”, 23 czerwca 2004 r.

W kształceniu zasobów pracy ważnym zagadnieniem jest zwrócenie uwagi na fakt, iż należy uwzględnić charakter obecnego rynku pracy oraz rynki pracy w przyszłości. Zasoby pracy dla aktualnych potrzeb gospodarki muszą uwzględniać popyt na określone kwalifikacje oraz niedopasowanie strukturalne kierunków kształcenia do funkcjonujących rynków pracy (Borowiec 2002). Przygotowanie zasobów pracy dla przyszłości musi nawiązać do nowych potrzeb wkraczania technologii informacyjnej, informatyzacji nowych sektorów go- 
spodarczych oraz potrzeb kadrowych dla dotychczas funkcjonujących sektorów, które stosunkowo mniej podatne są na zmiany technologiczne. W procesach transformacji przestrzennych układów przemysłowych, obok problematyki ekonomicznej, ważne są także działania społeczne warunkujące poziom życia ludności, który wynika m.in. z rozmiarów i jakości rynków pracy.

Przedstawione rozważania podnoszą znaczenie prac diagnostycznych i prognostycznych, a także prac związanych z wytyczaniem działań strategicznych mających na celu racjonalne sterowanie procesami transformacji przemysłu w różnej skali układów przestrzennych, zwłaszcza w skali ośrodków przemysłowych i regionalnych układów przemysłowych. Konieczna jest w tym zakresie ścisła współpraca zarządów przedsiębiorstw występujących na danym obszarze z samorządowymi władzami, a także odpowiednia świadomość społeczności regionalnej.

W świetle przedstawionych rozważań należy przyjąć, iż otwiera się przed nami nowa problematyka badawcza, związana z procesami transformacji przemysłowych układów przestrzennych. Zaproponowane ujęcie modelowe wskazuje, iż nie można rozpatrywać procesów transformacji firm wyłącznie z pozycji mikroekonomicznej, ale szerzej - w kontekście funkcjonowania i kształtowania się przestrzennych układów przemysłowych. Ważnym zagadnieniem jest analiza działań koordynacyjnych w zakresie zarządzania przedsiębiorstwami oraz współdziałania z samorządowymi układami lokalnymi i regionalnymi, a także z otoczeniem krajowym i międzynarodowym.

\section{Literatura}

Bandman M.K., 1976, Modelling of Territorial Production Complexes, vol. I, II, III, USSR Academy of Sciences. Sibberian Department Institute of Economics and Organization of Industrial Production. Novosibirsk.

Borowiec M., 2003, Zmiany kierunków ksztatcenia Akademii Ekonomicznej w Krakowie w latach transformacji gospodarki, [w:] Z. Zioło (red.), Problemy transformacji struktur przemysłowych, Prace Komisji Geografii Przemysłu PTG nr 4, Warszawa-Kraków-Rzeszów.

Boudeville J.R., 1966, Problems of Regional Economic Planning. Part I, Edinburgh.

Byrski B., 1970, Koordynacja gospodarki przedsiębiorstw w ośrodkach przemysłowych, Warszawa.

Chardonnet J., 1955, Podstawowe typy kompleksów przemysłowych, Przegl. Zagr. Lit. Geograf., z. 4.

Dobrowolska M., 1964, Tendencje rozwoju geografii przemystu w okresie XX-lecia Polski Ludowej, Przegl. Geograf., z. 4.

Dziewoński K., 1967, Baza ekonomiczna i struktura funkcjonalna miast, Prace Geograficzne nr 63, Warszawa.

Fajferek A., 1966, Region ekonomiczny i metody analiza regionalnej, Warszawa.

Fierla I., 1967, Przemyst, [w:] Struktura przestrzenna gospodarki narodowej, Warszawa.

Gierańczyk W., Stańczyk A., 2001, Okręgi przemysłowe w Polsce u progu XXI wieku, [w:] Z. Zioło (red.), Problemy przemian struktur przemysłowych $w$ procesie wdrażania regut gospodarki rynkowej, Prace Komisji Geografii Przemysłu PTG nr 3, Warszawa-Kraków-Rzeszów.

Hamilton F.E.J., 1977, The Definition and Character of Industrial Systems, Conference Papers, IGU, Commission on Industrial Systems, Kraków.

Herman S., 1967, Obszary koncentracji przestrzennej przemystu w Polsce w 1956 r., Biuletyn KPZK PAN, z. 5, Seria A.

Isard W., 1965, Metody analizy regionalnej, Warszawa. 
Kołosowski N., 1955, Zespót (kompleks) produkcyjno-terytorialny w radzieckiej geografii ekonomicznej. Przegl. Zagr. Lit. Geogr., z. 2.

Kortud B., 1968, Kraków jako ośrodek przemystowy. Rozwój i struktura przemystu wielkiego miasta. Prace Instytutu Geografii UJ, z. 41.

Leszczycki S., Grzeszczak J., Kukliński A., Najgrakowski M., 1961, Struktura przestrzenna przemystu w Polsce w latach 1956, Biuletyn KPZK PAN, z. 1(3).

Misztal S., 1962, Warszawski Okręg Przemystowy, Studia KPZK PAN, t. IV. Warszawa.

Misztal S., 1970, Przemiany struktury przestrzennej przemystu na ziemiach polskich w latach 18601965, Studia KPZK PAN, t. XXXI, Warszawa.

Pakuła L., 1962, Analiza struktury przestrzennych form koncentracji przemysłu województwa krakowskiego, Rocznik Naukowo-Dydaktyczny WSP w Krakowie, z. 10. Prace Geograficzne II, Kraków.

Probst A., 1974, Problemy rozmieszczenia przemyshu socjalistycznego, Warszawa.

Rachwał T., 2006, Efekty restrukturyzacji wybranych przedsiębiorstw przemystowych Polski Poludniowo-Wschodniej, [w:] Z. Zioło, T. Rachwał (red.), Efekty restrukturyzacji polskiej przestrzeni przemystowej, Prace Komisji Geografii Przemysłu PTG nr 9, Warszawa-Kraków.

Secomski K., 1956, Wstęp do teorii rozmieszczenia sit wytwórczych, Warszawa.

Zioło Z., 1970, Formy koncentracji przemystu w strukturze przestrzennej województwa rzeszowskiego, Rocznik Naukowo-Dydaktyczny WSP w Krakowie, z. 40. Prace Geograficzne V, Kraków.

Zioło Z., 1971, Stan badań nad problemem struktury przestrzennej przemyslu i jej form koncentracji, Materiały Informacyjne WKPG w Rzeszowie, styczeń-marzec, Rzeszów.

Zioło Z., 1976, The Development of Optimum Territorial Forms of Industrial Concentration, Geographia Polonica, vol. 33.

Zioło Z. 1980, Wpływ przemystu na rozwój społeczno-ekonomiczny regionu rzeszowskiego, Seria „Problemy rejonów uprzemysławianych” KBRU PAN, PWN, Warszawa.

Zioło Z., 1986, Model przemian struktur przemystowych, [w:] Z. Zioło (red.), Rozwój przemystu i przemiany struktury przestrzenno-gatęziowej województwa bielskiego w latach 1975-1986. BielskoBiała.

Zioło Z. (red.), 1988, Zakład przemysłowy w akademickim kształceniu nauczycieli geografii, Kraków.

Zioło Z. (red.), 1990, Problematyka ośrodka przemysłowego w akademickim ksztatceniu nauczycieli geografii, Kraków.

Zioło Z. (red.), 1993, Problematyka okręgu przemystowego w akademickim ksztatceniu nauczycieli geografii, Kraków.

Zioło Z., 1997, Miejsce struktury przestrzennej przemyslu w przestrzeni geograficznej, [w:] B. Domański (red.), Geografia-Człowiek-Gospodarka, Kraków.

\section{Transformational processes in industrial spatial structures in relation to changing surroundings}

The paper presents a model of transformational processes in spatial forms of industry concentration. The model distinguishes various types of enterprises: leading, complementary, standard, and internal-demand firms, and types of surroundings: regional, national, and international. The paper presents passive and active relations occurring among all those categories. 